\title{
Teeth number variation and cranial morphology within Vipera aspis group
}

\author{
Marco A.L. Zuffi \\ Museum of Natural History and Territory, University of Pisa, Italy. \\ Correspondence: Museum of Natural History and Territory, University of Pisa, via Roma 79, I-56011 Calci (Pisa), Italy. Phone: +39 0502212967 , \\ Fax: +39 0502212975; E-mail: marcoz@museo.unipi.it
}

Received: 18 March 2012; received in revised form: 23 November 2012; accepted: 1 February 2013.

The huge morphological variability of asp viper (Vipera aspis) snakes has been longly addressed and studied to solve systematic and phylogeographic questions, with emphasis mainly to external morphology, distributive patterns and genome analyses. Teeth number and skull size variation are presently considered in order to contribute to the definition of the morphological puzzle that characterise the asp viper, comparing these structures among age classes and subspecies. The results indicated that, on the whole, 1) teeth number did not vary between sexes, 2) right palatine, total palatine and right dental teeth number varied among taxa and 3) skull length was markedly dimorphic. These differences apparently are congruent to taxonomic position and published phylogeographic patterns.

Key words: Anatomical features; teeth count; Vipera aspis subspecies; western Europe.

Variación en el número de dientes y morfología craniana del grupo Vipera aspis. La gran variabilidad morfológica de la víbora aspid (Vipera aspis) ha sido investigada extensamente en el pasado para resolver problemas de sistemática y filogeografía, con especial énfasis en la morfología externa, patrones de distribución y análisis genéticos. Este estudio analiza la variación existente en el número de dientes y el tamaño del cráneo entre sexos y subespecies con el objetivo de contribuir a la resolución del rompecabezas morfológico existente en esta especie. Los resultados indican que, de modo general, 1) el número de dientes no varía entre sexos, 2) el número de dientes del palatino derecho, el número total de dientes palatinos y el número de dientes en la parte derecha del cráneo varía entre taxones, 3) la longitud del cráneo es marcadamente dimórfica. Nuestros resultados están en concordancia con la posición taxonómica y los patrones filogeográficos estudiados en esta especie.

Key words: número de dientes; oeste de Europa; rasgos anatómicos; subespecies de Vipera aspis.

Snake skulls represent unique features among vertebrate taxa, showing an impressive variability in both shape and size. Skull shape, more than size, has been used to describe taxonomic ranks, contributing to the systematics of the group (KraMER, 1980; GLOYD \& CONANT, 1990; LEE \& SCANLON, 2002). However, bones allometries are furthermore suitable for this purpose. Static and dynamic relationship of skull bones, movement of articulations or number of mobile and fixed bones among extant and extinct species have contributed to actual phylogeny (LEE \& SCANLON, 2002). At this respect, for example, the presence of a markedly reduced, mobile, maxilla with elongated fangs discriminate the Viperidae family from all the other serpents.

Skulls, on the other hand, have been studied for analysis of the kinematic of prey swallowing or when inspecting relationships between trophic resources and mouth opening in unrelated taxa (Ross et al., 2010). 
Furthermore, skull morphology and kinematics have been informative of adaptive functions in Lepidosauria (MetzGer, 2002). Despite its determinant value in phylogeny and systematics (CUNDAlL, 1981; LEE \& SCANLON, 2002), analytical data on snake skull morphology are relatively scarce: frequently snake skulls are simply figured, presented as drawings or pictures (BOULENGER, 1913; Kramer, 1980; Boughner et al., 2007; see also a general overview on http://en.wikipedia.org/wiki/Snake_skeleton), being rarely described in detail except when describing a species or when comparing different or related species (SCHÄTTI, 1988; Gloyd \& Conant, 1990; LeE \& SCANlon, 2002). Skull morphology is considered a conservative and little variable anatomical character that shows appreciable differences usually between distinct, unrelated genera and, less frequently, in closely related species (Joger et al., 1997). In general, bones constituting dorsal, lateral and ventral skull parts (i.e. parietal, basisphenoid) may differ in size and shape (i.e. interspecific differences, GENTILLI et al., 2009), or may display relative allometric development (i.e. shorter premaxillary bones and longer maxillary bone) during ontogenesis (ZUFF et al., 2011) or between sexes (VINCENT et al., 2004). More specifically, the distal skull portion (i.e. the neurocranium) is the less variable structure of the head (SCHÄTTI, 1988; GENTILli et al., 2009), while the proximal portion (i.e. the splancnocranium), on the contrary, is more susceptible to shape variability, due to functional demands related to dietary habits, as some studies demonstrate in several taxa (e.g. bats: VAN CAKENBERGHE $e$ et al., 2002; lizards: Metzger \& Herrel, 2005; snakes:
VINCENT et al., 2004). Integrative approaches including shape analysis or other characters such as scale patterns might provide insights of sexual dimorphism, taxonomic characteristics or functional structures (Kaliontzopoulou et al., 2007; Gentilli et al., 2009; AdAMs \& Nistri, 2010). Moreover, the inspection of skull anatomical and kinematic features could reveal hidden or unexpected phenomena (e.g. jaw closing inlever, Herrel et al., 2010). In the Viperidae, and especially in the European vipers, one of the most studied groups of snakes in the world, information on head skeletal features is still scarce (KRAMER, 1980; GENTILLI et al., 2009). While on one side, a wide and rich literature does exist on the evolution, function and structure of fangs (see KARDONG, 1982; Greene \& Fogden, 2000; JACKSON, 2003, among others), on the other side other teeth have received almost none or very little attention. Despite the fact that they do not show either particular adaptive meaning or special morphological differentiation, number of teeth could be relevant for systematic and taxonomic purposes.

The asp viper, Vipera aspis (L., 1758), is divided into four subspecies morphologically distinct, with allopatric distribution (Fig. 1; ZufFi \& BONNET, 1998; ZufFi, 2002; GOLAY et al., 2008), whose anatomical characteristics are not well studied (KRAMER, 1980; ZUFF 2002), resulting in a partially unresolved taxonomy (URSENBACHER et al., 2006; Golay et al., 2008; Barbanera et al., 2009; MASSETI \& ZuFFI, 2011).

This paper aims at describing the range variation in the number of non maxillary teeth among Vipera aspis subspecies and of some other Vipera species in order to: 


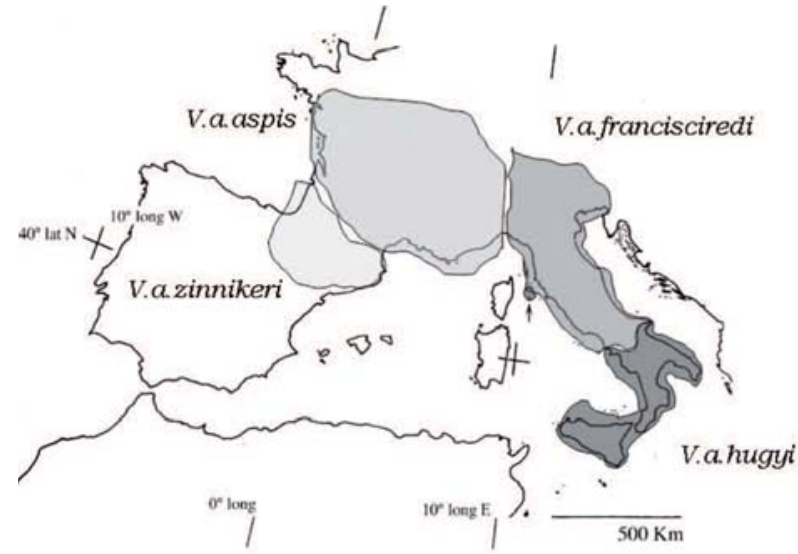

Figure 1: Vipera aspis ssp distribution.
1) verify sexual dimorphism variation in skull size and 2) assess any geographical pattern in teeth numbers, as a contribution to the overall knowledge of $V$. aspis.

\section{MATERIALS AND METHODS}

\section{Teeth count and cranial morphology}

Skulls of the "Enrica Calabresi" historical collection at the Zoological Museum "La Specola", University of Florence were examined. These specimens were described and three of them were also figured by Calabresi (see table IV in CALABRESI, 1924). Unfortunately in her paper, Calabresi (1924) was not able to discriminate to variation in teeth number and position, despite she reported variability for this parameter. For this study, I considered 55 specimens (Vipera aspis aspis $\mathrm{N}=6 ; V$. a. francisciredi $\mathrm{N}=24 ; V$. a. hugyi $\mathrm{N}=22 ; V$. berus berus $\mathrm{N}=3$; Appendix 1). Other skulls with incomplete information on sex or locality were discarded. For purely descriptive purposes, drawings of dorsal and ventral views of complete skulls are presented in Fig. 2. Teeth number was established considering the niche of each tooth along left (L) and right
(R) palatines, $\mathrm{L}$ and $\mathrm{R}$ pterygoids, and $\mathrm{L}$ and $\mathrm{R}$ dentals (Fig. 3). I also considered the total number of teeth pairing left and right niches of each bone, and the total number of teeth of palatine plus pterygoid bones. Count was performed under stereomicroscope at 6x magnification. Since some crania were incomplete, teeth niches counting was not possible in all cases, showing variation in sample size. I also
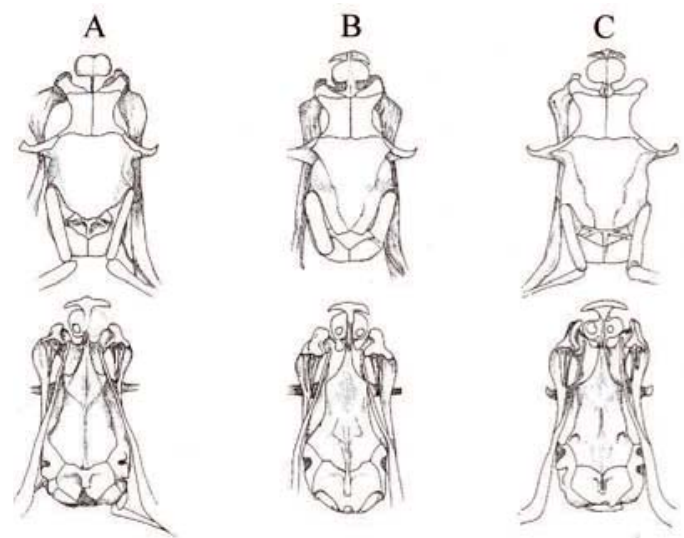

Figure 2: Dorsal (above) and ventral (below) view of V. aspis subspecies skulls. (A) V. a. aspis $\widehat{0}$, Monte Rosa, Piedmont, NW Italy, MZUF C315; (B) V. a. francisciredi $\hat{0}$, Udine, Friuli Venezia Giulia, NE Italy, MZUF C395; (C) V. a. hugyi + , Mongiana, Calabria, S Italy, MZUF C287 (taken from the Calabresi collection, Zoology Museum, University of Florence; original drawings of the author). 


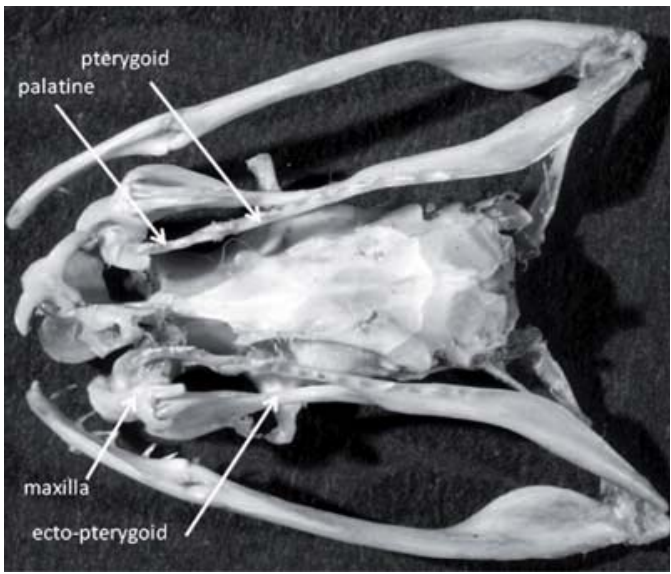

Figure 3: Ventral view of $V$. a. aspis skull (Calabresi collection, catalogue number C315, MZUF). Main dentary bones are shown with arrows.

measured overall length of Calabresi's skulls and of additional 16 skulls preserved in the Natural History Museum, University of Pisa, including three $V$. a. aspis; five $V$. a. francisciredi; two $V$. a. hugyi; one $V$. a. zinnikeri; one $V$. ammodytes; one $V$. berus; and three $V$. a. francisciredi $\mathrm{x}$ hugyi hybrids (see Appendix 1 for more details). Overall length was measured as the distance from the midline of frontals to the rear margin of the basioccipital bone (Fig. 4). For all available localities I also retrieved geographic coordinates (longitude and latitude), to perform further analyses on geographical variation.

\section{Statistical analyses}

Data were checked for normality (Kolmogorov-Smirnov test). Total number of palatine teeth, total number of pterygoid teeth, total number of dental teeth and total number (palatine + pterygoid) of teeth were normally distributed. All these parameters were also homogeneous (Levene test, all $P>0.05$ ). Distribution was not normal in $\mathrm{L}$ and $\mathrm{R}$ palati- ne teeth $(\mathrm{Z}=1.403, P=0.039$ and $\mathrm{Z}=1.677$, $P=0.0007$ respectively) and in the L pterygoid teeth $(\mathrm{Z}=1.494, P=0.023)$. Parametric tests were used in the case of normally distributed variables, while the rest of the variables were analysed using non parametric statistics. The analyses that considered all variables together were carried out with non parametric tests. Non parametric bivariate correlations (Spearman $\rho$ ) were performed on all teeth variables ( $\mathrm{L}$ and $\mathrm{R}$ palatines, $\mathrm{L}$ and $\mathrm{R}$ pterygoids, $L$ and $R$ dentals, total number of palatine teeth, total number of pterygoid teeth and total number of dental teeth; Table 1) and head length in order to test for any correlation. Kruskal-Wallis test was run on the total number of teeth per bone, with subspecies as factor. I performed a Hierarchical cluster analysis, with Agglomerative approach (each observation starts in its own cluster, and pairs of clusters are merged as one moves up the hierarchy) with Average Linkage (between groups) in order to classify any homogeneous group (taxa and area); furthermore, with free R statistical package ( $R$ Development Core TEAM, 2011), I run a Mantel test statistic based on Pearson's product-moment correlation [Call: mantel ( $x d i s=$ MM.dist, $y d i s=$ MD.dist), where

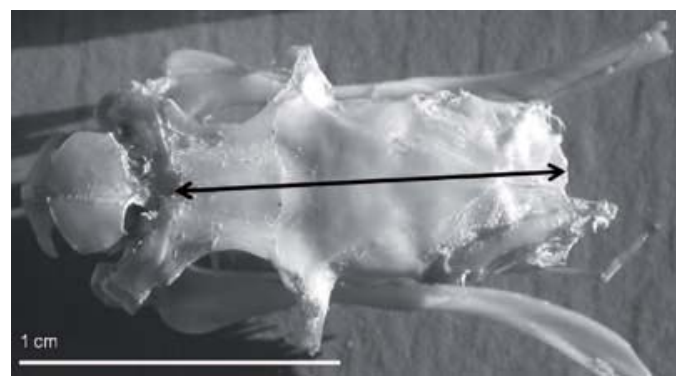

Figure 4: Dorsal view of $V$. a. francisciredi skull, showing skull length measurement (Calabresi collection, catalogue number C399, MZUF). 
Table 1: Average value, standard deviation and sample size (in parenthesis) of the number of teeth for each $V$. aspis subspecies and sex. $\mathrm{L}=$ left; $\mathrm{R}=$ right.

\begin{tabular}{|c|c|c|c|c|c|c|c|c|c|}
\hline & \multicolumn{3}{|c|}{ Palatine } & \multicolumn{3}{|c|}{ Pterygoid } & \multicolumn{3}{|c|}{ Dental } \\
\hline & $\mathrm{L}$ & $\mathrm{R}$ & Total & $\mathrm{L}$ & $\mathbf{R}$ & Total & $\mathrm{L}$ & $\mathrm{R}$ & Total \\
\hline \multicolumn{10}{|l|}{ Males } \\
\hline V.a. aspis & $4 \pm 0.01(3)$ & $4 \pm 0.02(2)$ & $8 \pm 0.03(2)$ & $12.7 \pm 0.6(3)$ & $12 \pm 1.4(2)$ & $24.5 \pm 2.1(2)$ & $15.7 \pm 0.6(3)$ & $14.5 \pm 0.7(2)$ & $30 \pm 0.02(2)$ \\
\hline V. a. francisciredi & $3 \pm 0.8(11)$ & $2.8 \pm 0.7(11)$ & $5.9 \pm 1.4(10)$ & $10.8 \pm 2.6(11)$ & $10.6 \pm 2.4(12)$ & $21.3 \pm 5(11)$ & $13.7 \pm 1.8(9)$ & $14.4 \pm 0.9(8)$ & $28.5 \pm 1.4(6)$ \\
\hline V. a. hugyi & $2.7 \pm 0.7(10)$ & $2.9 \pm 0.4(8)$ & $5.7 \pm 1.1(6)$ & $11.8 \pm 1.5(10)$ & $12.1 \pm 1.2(9)$ & $24.6 \pm 2.6(7)$ & $15.3 \pm 1.1(9)$ & $15.1 \pm 0.9(11)$ & $30.4 \pm 2(8)$ \\
\hline V.a.berus & $4(1)$ & $4(1)$ & $8(1)$ & $12(1)$ & $11(1)$ & $23(1)$ & $16(1)$ & $16(1)$ & $32(1)$ \\
\hline \multicolumn{10}{|l|}{ Females } \\
\hline V.a. aspis & $3(1)$ & $4 \pm 0.1(2)$ & $7(1)$ & $11(1)$ & $11.5 \pm 0.7(2)$ & $23(1)$ & - & $14.5 \pm 2.1(2)$ & - \\
\hline V. a. francisciredi & $2.6 \pm 0.5(7)$ & $2.6 \pm 0.5(9)$ & $5.1 \pm 0.9(7)$ & $10.6 \pm 1.4(9)$ & $10.6 \pm 1.7(9)$ & $21.1 \pm 2.8(9)$ & $14.7 \pm 2(8)$ & $13.7 \pm 1.1(8)$ & $28.5 \pm 2.7(8)$ \\
\hline V.a. hugyi & $2.6 \pm 0.8(7)$ & $2.8 \pm 0.9(8)$ & $5.1 \pm 1.6(7)$ & $11.6 \pm 0.8(7)$ & $11.1 \pm 1.4(8)$ & $22.7 \pm 2(7)$ & $14.8 \pm 1.8(5)$ & $15 \pm 0.6(7)$ & $30.2 \pm 1.7(4)$ \\
\hline V. a. berus & $4(1)$ & $5(1)$ & $9(1)$ & $13(1)$ & $13(1)$ & $26(1)$ & $15(1)$ & $14(1)$ & $29(1)$ \\
\hline
\end{tabular}

MM is the morphometric matrix (average data of teeth number), as Euclidean distance, and $\mathrm{MD}$ is the geographic matrix (distance in kilometres between pairs of localities)].

Probability was set at $\alpha=0.05$, and statistical analyses were performed with SPSS 13.0 release 2005 for Windows (SPSS Inc., Chicago, Illinois, USA) and $\mathrm{R}$, version 2.15.2 ( ${ }^{\circ} \mathrm{R}$ Foundation for Statistical Computing, Vienna, Austria).

\section{RESULTS}

Descriptive statistics regarding the number of teeth per bony section for each subspecies are detailed in Table 1.

Spearman correlation was positively significant between all pairs of splacnocranium teeth, while only total pterygoid teeth and total palatine+total pterygoid teeth correlated to right dental teeth $(\mathrm{N}=35$, $\rho=0.408, P=0.015$ and $\mathrm{N}=32, \rho=0.361$, $P=0.042$ respectively); head length correlated only slightly with $\mathrm{L}$ palatine teeth $(\mathrm{N}=46$, $\rho=-0.290, P=0.05)$ and negatively with palatine+pterygoid teeth $(\mathrm{N}=40, \rho=-0.341$,
$P=0.032)$. All other correlations were not significant. Kruskal-Wallis test was significant only with taxon effect on $\mathrm{L}$ palatine $(\mathrm{Z}=13.156$, d.f. $=3, P=0.004)$, R palatine $(Z=19.005$, d.f. $=3, P<0.0001)$, and R dental teeth $(Z=9.815$, d.f. $=3, P=0.02)$. Relationship between number of teeth and skull length (preserved skulls), compared between sexes, age classes and taxa, showed that sexual dimorphism is absent at teeth level, that palatine teeth number varied among taxa and that there was a marked sexual difference in skull length. Hierarchical cluster showed a first cluster of southern asp vipers ( $V$. a. hugyi), and a second large cluster with two subclusters: central and northeastern asp vipers ( $V$. $a$. francisciredi) plus northwestern asp vipers (V. a. aspis-V. a. atra) (Fig. 5). Regarding the spatial correlation between geographic distance and the number of teeth of each taxa, the Mantel test did not find correlation between the average teeth number and the geographic distance (Mantel statistic $\mathrm{r}=-0.155, P=0.964$, based on 999 permutations, after standardization). 


\section{DisCUSSION}

CALABRESI (1924) experimented the modern idea of comparing external and internal anatomy in order to solve taxonomical matters, and in addition to scalation and colour analyses, she extracted skulls from specimens preserved in liquid. She found differences among northern and northeastern Italy plus central Italy vs. northwestern Italy asp vipers (now $V$. $a$. francisciredi vs $V$. a. aspis respectively, as forma $I$ vs. forma II), but especially she found a clear differentiation between these two subspecies and the one in the southern part of Italy V.a. hugyi (forma III) (CALABRESI, 1924: pp. 118119). Kramer (1980) had difficulties in separating $V$. a. atra (now $V$. a. aspis) from $V$. a. hugyi, even if he used potentially suitable ratios derived from osteological measures (Kramer, 1980: pp. 5-6). As declared
(Kramer, 1980: p. 5, table and description of $V$. a. atra distribution), specimens from northeastern ( $V . \quad a . \quad$ aspis $)$ and southern Apennines ( $V$. a. hugyi) were considered together, therefore introducing a strong bias in his analyses and preventing any firm conclusion. On the contrary, GeNTILLI et al. (2009), using dorsal and ventral skull shapes, showed that the highest divergence was between $V$. a. aspis vs $V$. a. francisciredi- $V$. a. hugyi, and a secondary, less marked, divergence between $V$. a. franciscire$d i$ and $V$. a. hugyi. Sexual differences were not considered (CALABRESI, 1924; KRAMER, 1980) or were found negligible (GENTILLI et al., 2009).

In all these papers, however, relatively low or no attention at all was paid to teeth. Teeth in snakes have frequently been used in anatomical studies (see for instance HANDRIGAN \& RICHMAN, 2011) as a tool that discriminates, throughout the evolution of snakes, between

\section{Rescaled Distance Cluster Combine}

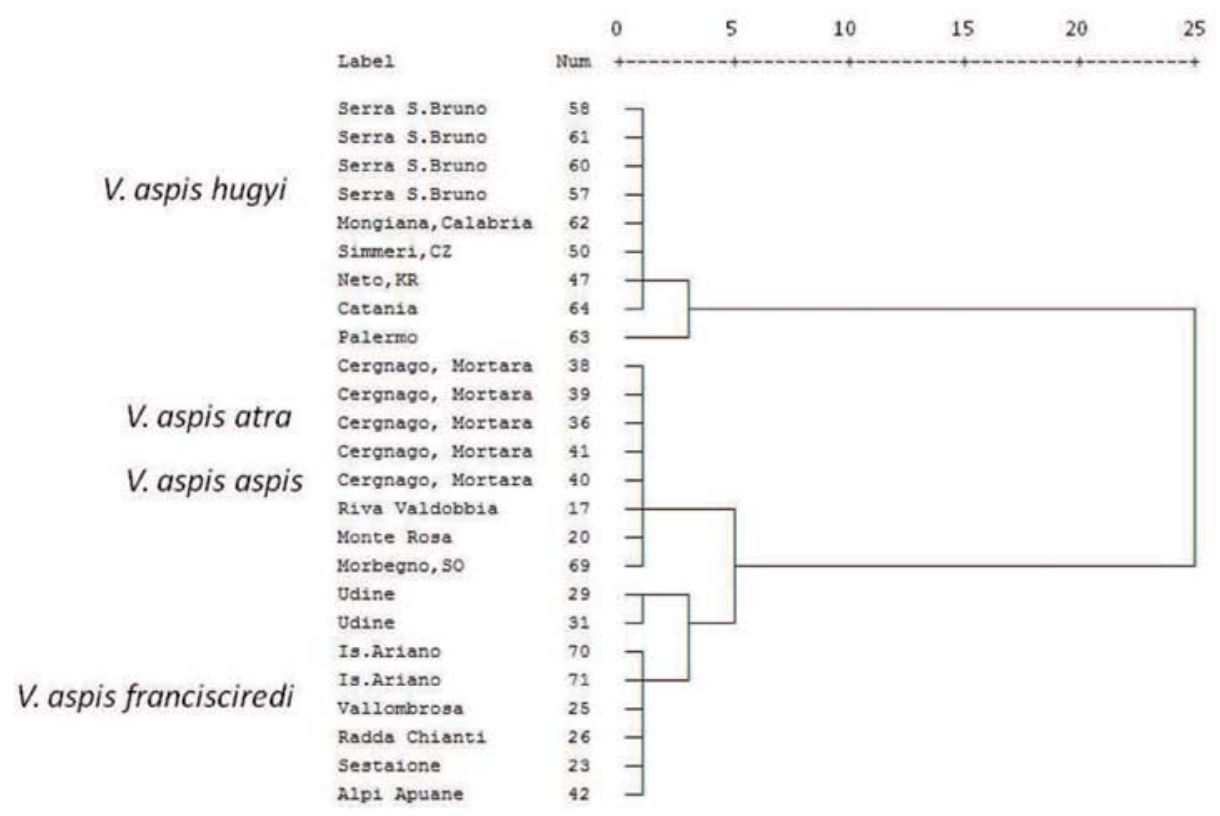

Figure 5: Hierarchical cluster analysis on teeth number and taxa in Vipera aspis. 
venomous and harmless snakes (KARDONG, 1982). The use of snakes' teeth in palaeontology is quite rare (but see SZYNDLAR, 1991) despite it has been proved to be extremely useful (GONG et al., 2010). However, recently, differential teeth morphology in a very specialized species has been described being associated with different dietary habits (JACKSON \& FRITTS, 2004). Vipera aspis subspecies have a similar trophic spectrum, and no sexual differences have been reported in the diet across all the distribution area (see Luiselli \& Agrimi, 1991; SAVIOZZI \& ZUFFI, 1997). This suggests that differences observed in this study in teeth number are due to selective pressures other than diet. Interestingly, different teeth number (e.g. palatine and dental teeth) was related to taxonomic assignment (Hierarchical Cluster Analysis, Fig. 4) and not to the geographic distribution itself. In fact, the Mantel test did not support any spatial correlation between geographic distance and the number of teeth. These results support previous papers (Pozio, 1980; ZufFi, 2002; BARBANERA et al., 2009; GENTILLI et al., 2009) confirming differences in the number of teeth at taxonomical level. The role and meaning of all these dentary features should be carefully investigated in future studies to understand what selective forces are responsible for these differences, and to properly address the asp viper systematic position (see ZUFFI, 2002).

\section{Acknowledgement}

Annamaria Nistri (La Specola Museum, University of Florence) allowed access to the Enrica Calabresi skull collection. Roberto Sacchi (University of Pavia) helped in run- ning Mantel test with $\mathrm{R}$ package. Suggestions and criticisms of two anonymous reviewers and those of Ana Perera highly improved a previous version of this ms.

\section{REFERENCES}

Adams, D.C. \& Nistri, A. (2010). Ontogenetic convergence and evolution of foot morphology in European cave salamanders (Family: Plethodontidae). BMC Evolutionary Biology 10: 216.

Barbanera, F; Zuffi, M.A.L.; Guerrini, M.; Gentilli, A.; Tofanelli, S.; Fasola, M. \& Dini, F. (2009). Phylogeography of the Italian asp viper (Vipera aspis) as inferred from mitochondrial and microsatellite DNA data. Molecular Phylogenetics and Evolution 52: 103-114.

Boughner, J.C.; Buchtova, M.; Fu, K., Diewert, V., Hallgrímsson, B. \& RiCHMAN, J.M. (2007). Embryonic development of Python sebae - I: Staging criteria and macroscopic skeletal morphogenesis of the head and limbs. Zoology 110: 212-230.

Boulenger, G.A. (1913). The snakes of Europe. $2^{\text {nd }}$ ed. Methuen \& Co., Ltd., London, UK.

Calabresi, E. (1924). Ricerche sulle variazioni della Vipera aspis Auct. in Italia. Bollettino dell'Istituto di Zoologia della Regia Università di Roma 2: 78-127.

Cundall, D. (1981). Cranial osteology of the Colubrid snake genus Opheodrys. Copeia 1981: 353-371.

Gentilli, A.; Cardini, A.; Fontaneto, D. \& ZufFI, M.A.L. (2009). The phylogenetic signal in cranial morphology of Vipera aspis: a contribution from geometric morphometrics. The Herpetological Journal 19: 69-77. 
Gloyd, H.K. \& Conant, R. (1990). Snakes of the Agkistrodon complex: a monographic review. SSAR, St. Louis, Missouri, USA.

Golay, P.; Monney, J.-C.; Conelli, A.; Durand, T.; Thiery, G.; Zuffi, M.A.L. \& URsenbaCher, S. (2008). Systematics of the Swiss asp vipers: some implications for the European Vipera aspis (Linnaeus, 1758) complex (Serpentes: Viperidae) - A tribute to Eugen Kramer. AmphibiaReptilia 29: 71-83.

Gong, E.; Martin, L.M.; Burnham, D.A. \& FALK, A.R. (2010). The birdlike raptor Sinornithosaurus was venomous. Proceedings of the National Academy of Sciences 107: 766-768.

Greene, H.W. \& Fogden, M. (2000). Snakes: the Evolution of Mystery in Nature. University of California Press, Los Angeles, California, USA.

HANDRIGAN G.R. \& RichMAN J.M. (2011). Unicuspid and bicuspid tooth crown formation in Squamates. Journal of Experimental Zoology B 316: 598-608.

Herrel, A.; Moore, J.A.; BredeweG, E.M. \& Nelson, N.J. (2010). Sexual dimorphism, body size, bite force and male mating success in tuatara. Biological Journal of the Linnean Society 100: 287-292.

Kaliontzopoulou, A.; Carretero, M.A. \& LlORENTE, G.A. (2007). Multivariate and geometric morphometrics in the analysis of sexual dimorphism variation in Podarcis lizards. Journal of Morphology 268: 152-165.

KaRDONG, K.V. (1982). The evolution of the venom apparatus in snakes from colubrids to viperids and elapids. Memórias do Instituto Butantan 46: 105-118.
Kramer, E. (1980). Zum skelett der Aspisviper, Vipera aspis (Linnaeus, 1758). Revue Suisse de Zoologie 87: 3-16.

JACKSON, K. (2003). The evolution of venom-delivery systems in snakes. Zoological Journal of the Linnean Society 137: 337-354.

JaCKSON, K. \& FritTs, T.H. (2004). Dentitional specialisations for durophagy in the Common Wolf snake, Lycodon aulicus capucinus. Amphibia-Reptilia 25: 247254.

Joger, U.; Lenk, P.; Baran, I.; Böhme, W.; Ziegler, T.; Heidrich, P. \& Wink, M. (1997). The phylogenetic position of Vipera barani and V. nikolskii within the Vipera berus complex, In W. Böhme, W. Bischoff \& T. Ziegler (eds.) Herpetologia Bonnensis. Societas Europaea Herpetologica, Bonn, Germany, pp. 185-194.

LeE, M.S.Y. \& SCANLON, J.D. (2002). Snake phylogeny based on osteology, soft anatomy and ecology. Biological Reviews 77: 333-401.

Luiselli, L. \& AgRimi, U. (1991). Composition and variation of the diet of Vipera aspis francisciredi in relation to age and reproductive stage. Amphibia-Reptilia 12: 137-144.

Masseti, M. \& Zuffi, M.A.L. (2011). On the origin of the asp viper Vipera aspis hugyi Schinz, 1833, on the island of Montecristo, Northern Tyrrhenian Sea (Tuscan archipelago, Italy). Herpetological Bulletin 117: 1-9.

Metzger, K. (2002). Cranial kinesis in Lepidosaurs: skulls in motion, In P. Aerts, K. D'Août, A. Herrel \& R. Van Damme (eds.) Topics in Functional and Ecological Vertebrate Morphology. Shaker Publishing, Maastricht, Netherlands, pp. 15-46. 
Metzger, K. \& Herrel, A. (2005). Correlations between lizard cranial shape and diet: a quantitative, phylogenetically informed analysis. Biological Journal of the Linnean Society 86: 433-466.

PozIO, E. (1980). Contributo alla sistematica di Vipera aspis (L.) mediante analisi elettroforetica delle proteine contenute nel veleno. Natura 71: 28-34.

R Development Core Team (2011). $R: A$ Language and Environment for Statistical Computing. R Foundation for Statistical Computing, Vienna, Austria. Available at http://www.R-project.org/.

Ross, C.F.; Baden, A.L.; Georgi, J.; Herrel, A.; Metzger, K.A.; Reed, D.A., Schaerlaeken, V. \& WolfF, M.S. (2010). Chewing variation in lepidosaurs and primates. Journal of Experimental Biology 213: 572-584.

SAVIOZZI, P. \& ZuFFI, M.A.L. (1997). An integrated approach to the study of the diet of Vipera aspis. Herpetological Review 28: 23-24. SCHÄтTI, B. (1988). Systematik und Evolution der Schlangengattung Hierophis Fitzinger 1843 (Reptilia, Serpentes). Ph.D. Dissertation, University of Zurich, Zurich, Switzerland.

SZYNDLAR, Z. (1991). A review of Neogene and Quaternary snakes of central and eastern Europe. Part 11: Natricinae, Elapidae, Viperidae. Estudios geologicos 47: 237-266.

Ursenbacher, S., Conelli, A., Golay, P., Monney, J.-C., Zuffi, M.A.L., ThIERrY, G., Durand, T. \& Fumagalli, L. (2006). Phylogeography of the asp viper (Vipera aspis) inferred from mitochondrial DNA sequence data: evidence for multiple Mediterranean refuges. Molecular Phylogenetics and Evolution 38: 546-552. Van Cakenberghe, V.; Herrel, A. \& AguirRe, L.F. (2002). Evolutionary relationships between cranial shape and diet in bats (Mammalia: Chiroptera), In P. Aerts, K. D'Août, A. Herrel \& R. Van Damme (eds.) Topics in Functional and Ecological Vertebrate Morphology. Shaker Publishing, Maastricht, Netherlands, pp. 205-236.

Vincent, S.E.; HerRel, A. \& IrSChick, D.J. (2004). Ontogeny of intersexual head shape and prey selection in the pitviper Agkistrodon piscivorus. Biological Journal of the Linnean Society 81: 151-159.

Zuffi, M.A.L. (2002). A critique of the systematic position of the asp viper subspecies Vipera aspis aspis (Linnaeus, 1758), Vipera aspis atra Meisner, 1820, Vipera aspis francisciredi Laurenti, 1768, Vipera aspis hugyi Schinz, 1833 and Vipera aspis zinnikeri Kramer, 1958. AmphibiaReptilia 23: 191-213.

Zuffi, M.A.L. \& BONNET, X. (1999). Italian subspecies of the asp viper, Vipera aspis: patterns of variability and distribution. Italian Journal of Zoology 66: 87-95.

Zuffi, M.A.L.; SACCHI, R.; PupIN, F. \& Cencetti, T. (2011). Sexual size and shape dimorphism in the Moorish gecko (Tarentola mauritanica, Gekkota, Phyllodactylidae). North-Western Journal of Zoology 7: 189-197. 
Appendix 1: Specimens examined in this study. No = museum catalog number. Hybrids determined as in GENTILLI et al. (2009).

\begin{tabular}{|c|c|c|c|c|}
\hline No & Taxon & Sex & Locality & Museum \\
\hline T65 & V.a. aspis & male & Chizè, Deux Sevres, NW France & Pisa \\
\hline F37 & V.a. aspis & female & Chizè, Deux Sevres, NW France & Pisa \\
\hline 1188 & $V$. a. aspis & male & Gressoney La Trinitè, NW Italy & Pisa \\
\hline 741 & V. a. francisciredi & male & Arnino, Pisa, C Italy & Pisa \\
\hline $741 / 3$ & V. a. francisciredi & male & Arnino, Pisa, C Italy & Pisa \\
\hline 170 & V. a. francisciredi & male & Torretta, Pavia, N Italy & Pisa \\
\hline 170 & V. a. francisciredi & female & Torretta, Pavia, N Italy & Pisa \\
\hline 688 & V. a. francisciredi & male & S.Quirino, Lucca, C Italy & Pisa \\
\hline 1169 & V. a. hugyi & male & Torre del Loto, Taranto, S Italy & Pisa \\
\hline 1187 & V. a. hugyi & female & Montecristo Is., C Italy & Pisa \\
\hline 1168 & V.a. zinnikeri & male & Albeva, Catalonia, Spain & Pisa \\
\hline 1186 & $V$. ammodytes & female & Krk Is., Croatia & Pisa \\
\hline 701 & V. berus & female & Verona surroundings, N Italy & Pisa \\
\hline 1170 & hybrid franc $x$ hugyi & male & S. Anastasia, Naples, S Italy & Pisa \\
\hline 1171 & hybrid franc $x$ hugyi & male & Clanio valley, Avellino, S Italy & Pisa \\
\hline 1172 & hybrid franc $x$ hugyi & male & Clanio valley, Avellino, S Italy & Pisa \\
\hline C490 & V. a. aspis & male & Riva Valdobbia, Novara, NW Italy & Florence \\
\hline $\mathrm{C} 132$ & V.a. aspis & female & Alpi d'Ossola, Novara, NW Italy & Florence \\
\hline C87 & V. a. aspis & juvenile & Calasca, Novara, NW Italy & Florence \\
\hline C315 & V. a. aspis & male & Mount Rosa, NW Italy & Florence \\
\hline C315 & V.a. aspis & female & Mount Rosa, NW Italy & Florence \\
\hline C626 & V. a. aspis & male & Lanzo valleys, Turin, NW Italy & Florence \\
\hline \multirow[t]{2}{*}{ C96 } & V. a. francisciredi & male & Sestaione, Pistoia, C Italy & Florence \\
\hline & V. a. francisciredi & female & Poggio Riparghera, Florence, C Italy & Florence \\
\hline C697 & V. a. francisciredi & female & Vallombrosa, Florence, C Italy & Florence \\
\hline C699 & V. a. francisciredi & male & Radda Chianti, Florence, C Italy & Florence \\
\hline C583 & V. a. francisciredi & male & S. Croce Avellana, Florence, C Italy & Florence \\
\hline C139 & V. a. francisciredi & male & Treviso, NE Italy & Florence \\
\hline C399 & V. a. francisciredi & male & Udine, NE Italy & Florence \\
\hline C399 & V. a. francisciredi & male & Udine, NE Italy & Florence \\
\hline C399 & V. a. francisciredi & female & Udine, NE Italy & Florence \\
\hline C96 & V. a. francisciredi & male & Sestaione, C Italy & Florence \\
\hline C399 & V. a. francisciredi & female & Udine, NE Italy & Florence \\
\hline C399 & V. a. francisciredi & female & Udine, NE Italy & Florence \\
\hline C399 & V. a. francisciredi & juvenile & Udine, NE Italy & Florence \\
\hline C312 & V. a. francisciredi & male & Cergnago, Pavia, NW Italy & Florence \\
\hline C312 & V. a. francisciredi & male & Cergnago, Pavia, NW Italy & Florence \\
\hline C312 & V. a. francisciredi & male & Cergnago, Pavia, NW Italy & Florence \\
\hline C312 & V. a. francisciredi & female & Cergnago, Pavia, NW Italy & Florence \\
\hline C312 & V. a. francisciredi & female & Cergnago, Pavia, NW Italy & Florence \\
\hline C312 & V. a. francisciredi & female & Cergnago, Pavia, NW Italy & Florence \\
\hline C60 & V. a. francisciredi & female & Alpi Apuane, C Italy & Florence \\
\hline C95 & V. a. francisciredi & male & Bagni di Lucca, Lucca, C Italy & Florence \\
\hline
\end{tabular}




\section{Appendix 1 (cont.)}

\begin{tabular}{|c|c|c|c|c|}
\hline No & Taxon & Sex & Locality & Museum \\
\hline \multirow[t]{3}{*}{ C95 } & V. a. francisciredi & female & Bagni di Lucca, Lucca, C Italy & Florence \\
\hline & V. a. francisciredi & male & S Rossore, Pisa, C Italy & Florence \\
\hline & V. a. francisciredi & female & S Rossore, Pisa, C Italy & Florence \\
\hline $\mathrm{C} 573$ & V. a. hugyi & male & Neto, Crotone, S Italy & Florence \\
\hline $\mathrm{C} 573$ & V.a. hugyi & female & Neto, Crotone, S Italy & Florence \\
\hline C580 & V. a. hugyi & male & Simmeri, Catanzaro, S Italy & Florence \\
\hline C580 & V. a. hugyi & male & Simmeri, Catanzaro, S Italy & Florence \\
\hline C580 & V. a. bugyi & juvenile & Simmeri, Catanzaro, S Italy & Florence \\
\hline C620 & $V$. a. bugyi & male & Serra S. Bruno, Catanzaro, S Italy & Florence \\
\hline C620 & V. a. hugyi & male & Serra S. Bruno, Vibo Valenzia, S Italy & Florence \\
\hline C620 & V.a. hugyi & male & Serra S. Bruno, Vibo Valenzia, S Italy & Florence \\
\hline C620 & V. a. bugyi & male & Serra S. Bruno, Vibo Valenzia, S Italy & Florence \\
\hline C620 & V. a. hugyi & male & Serra S. Bruno, Vibo Valenzia, S Italy & Florence \\
\hline C541 & V. a. hugyi & male & Serra S. Bruno, Vibo Valenzia, S Italy & Florence \\
\hline C620 & $V$. a. bugyi & female & Serra S. Bruno, Vibo Valenzia, S Italy & Florence \\
\hline C541 & V. a. hugyi & female & Serra S. Bruno, Vibo Valenzia, S Italy & Florence \\
\hline C620 & V.a. hugyi & female & Serra S. Bruno, Vibo Valenzia, S Italy & Florence \\
\hline C620 & V. a. bugyi & female & Serra S. Bruno, Vibo Valenzia, S Italy & Florence \\
\hline C287 & V. a. hugyi & female & Mongiana, Vibo Valenzia, S Italy & Florence \\
\hline C640 & V. a. hugyi & male & Palermo, Sicily & Florence \\
\hline C317 & V. a. bugyi & juvenile & Catania, Sicily & Florence \\
\hline C199 & V. a. hugyi & male & Montecristo Is., C Italy & Florence \\
\hline C199 & V.a. hugyi & male & Montecristo Is., C Italy & Florence \\
\hline C199 & V. a. bugyi & female & Montecristo Is., C Italy & Florence \\
\hline C199 & V. a. hugyi & female & Montecristo Is., C Italy & Florence \\
\hline C414 & V. berus & male & Morbegno, Sondrio, N Italy & Florence \\
\hline C530 & $V$. berus & juvenile & Is. Ariano, Ferrara, NE Italy & Florence \\
\hline C530 & $V$. berus & female & Is. Ariano, Ferrara, NE Italy & Florence \\
\hline
\end{tabular}

